\title{
The gradual reinforcement of Japanese mapping in pre- colonial Taiwan and Korea
}

\author{
Shigeru Kobayashi ${ }^{\mathrm{a}, *}$ \\ a Professor Emeritus of Osaka University; Osaka University of Tourism \\ * Corresponding author
}

Keywords: Transition to Modern Mapping, East Asia, Japan, Taiwan, Korea

\begin{abstract}
:
In East Asia, the modern hydrographical survey was promoted during the Opium War (1840-1842) and the Arrow War (1856-1860) by Western countries, which demanded the establishment of modern trade relations with this area. However, the application of modern mapping such as triangulation to its inlands was limited even at the end of the nineteenth century, because it required stable and innovative governments for implementation. Keeping this uneven extension of modern cartography in East Asia in mind, we should pay attentions also to various map makings, which had been carried out in most of the inlands, in order to unravel the process of transition from early modern to modern cartography. In this presentation, I would like to follow up Japanese mappings in Taiwan and Korea to scrutinize their role for the preparation of modern survey,

Japan had little geographical information of neighbouring countries except China at the start of the Meiji Government, because of the long national seclusion during the Tokugawa Era, Accordingly, it depended heavily on foreign source in this period. Concerning Korea, Japanese army printed a large map titled "A complete map of Korea" (Fig. 1), compiling Western charts, native maps of Korea, and maps of China, which were affiliated with the Qing Imperial Atlas of the $18^{\text {th }}$ century. As for Taiwan, various materials including Western charts, maps prepared by an American former consul at Amoy and a Chinese administrative map copied secretly at the residence of a high official of Taiwan were gathered and translated into Japanese for the use of military expedition in 1874.
\end{abstract}

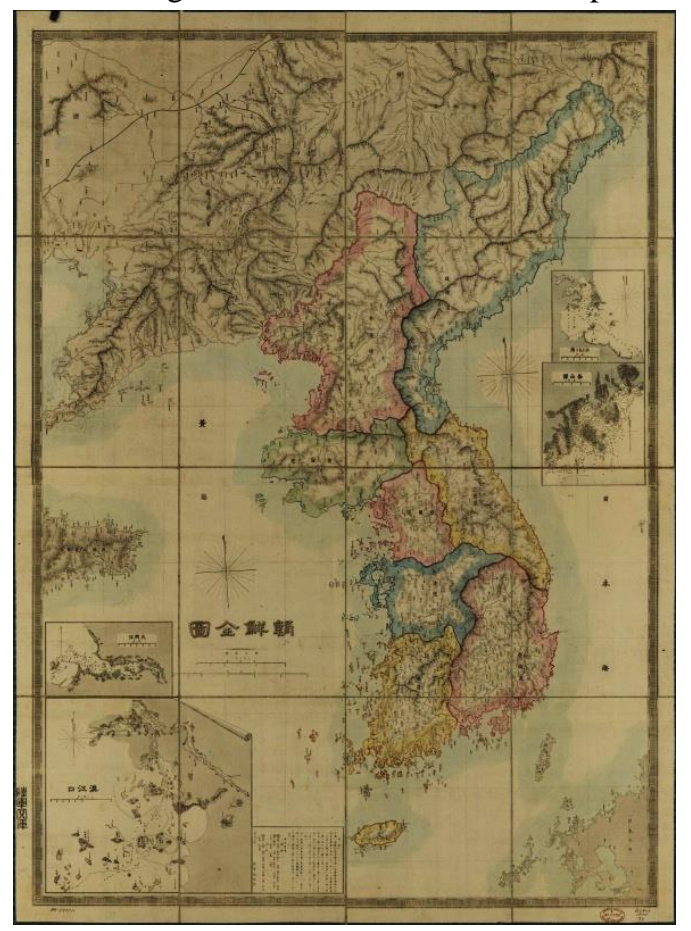

Figure 1. Revised edition of “A complete map of Korea” (1876)

However, a stark contrast is found concerning subsequent map making in these two areas. After the treaty of Kanghwa (1876), Japanese navy promoted hydrographical survey of coasts of Korea, which had not been surveyed yet by Western ships under the pretext of the search of new treaty port. In addition, army officers were dispatched to Japanese diplomatic offices in Korea for land survey after the Imo Military Rebellion (1882). Traversing with compass and pacing was commonly conducted by them. Up to the start of the Sino-Japanese War (1894), Japanese army prepared 64 sheets of 1: 200,000 maps to cover most of the territory of Korea compiling geographical information 
accumulated mainly during 1880s. In contrast, only one sheet of 1: 200,000 and one sheet of 1:500,000 maps were printed till the end of 1894 for Taiwan, which had been unexpected to be battlefield (Fig.2) .

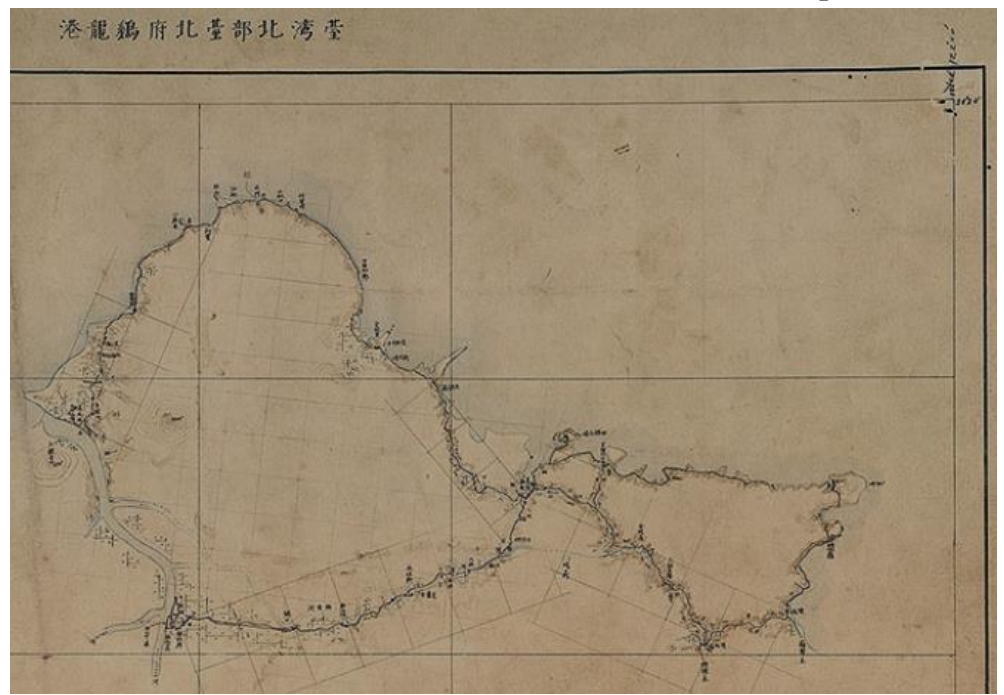

Fig. 2. Manuscript map of northern Taiwan (1: 200,000) by Tokuhei Ozawa (1888), which seems to have been utilized to compile 1: 200,000 map printed in 1895 by the Japanese Land Survey

However, Japanese army concentrated surveyors to Taiwan for plane table surveying after the conclusion of the peace treaty of Shimonoseki (1895), in which the cession of Taiwan was specified. Until 1903, 147 sheets of 1: 50,000 and 1: 20,000 maps, which covered coastal areas, were completed. Although the same kind of military survey was started in Korea, it took longer time to cover the whole area than that in Taiwan, mainly because of the native people's resistance movements against it.

Subsequent cadastral and topographical surveys including triangulation in colonial Taiwan and Korea were carried out on the basis of these preceding mappings. In addition to geographical knowledge summarized in these transitional maps, surveyors who had mastered specialized skills during the wartime mapping played important roles in these colonial projects. It should be also noted native youth were trained and hired for these surveys. 